\title{
A comparison of individual cow versus group concentrate allocation strategies on dry matter intake, milk production, tissue changes, and fertility of Holstein-Friesian cows offered a grass silage diet
}

\author{
M. W. Little,${ }^{*}{ }^{1}$ N. E. O'Connell, $†$ and C. P. Ferris ${ }^{*}$ \\ *Agri-Food and Biosciences Institute, Sustainable Agri-Food Sciences Division, Large Park, Hillsborough, BT26 6DR, United Kingdom \\ †Institute for Global Food Security, Queen's University Belfast, Northern Ireland Technology Centre, Malone Road, Belfast, BT9 5HN, \\ United Kingdom
}

\begin{abstract}
A diverse range of concentrate allocation strategies are adopted on dairy farms. The objectives of this study were to examine the effects on cow performance [dry matter (DM) intake (DMI), milk yield and composition, body tissue changes, and fertility] of adopting 2 contrasting concentrate allocation strategies over the first $140 \mathrm{~d}$ of lactation. Seventy-seven Holstein-Friesian dairy cows were allocated to 1 of 2 concentrate allocation strategies at calving, namely group or individual cow. Cows on the group strategy were offered a mixed ration comprising grass silage and concentrates in a 50:50 ratio on a DM basis. Cows on the individual cow strategy were offered a basal mixed ration comprising grass silage and concentrates (the latter included in the mix to achieve a mean intake of $6 \mathrm{~kg} / \mathrm{cow}$ per day), which was formulated to meet the cow's energy requirements for maintenance plus $24 \mathrm{~kg}$ of milk/cow per day. Additional concentrates were offered via an out-of-parlor feeding system, with the amount offered adjusted weekly based on each individual cow's milk yield during the previous week. In addition, all cows received a small quantity of straw in the mixed ration part of the diet (approximately $0.3 \mathrm{~kg} /$ cow per day), plus $0.5 \mathrm{~kg}$ of concentrate twice daily in the milking parlor. Mean concentrate intakes over the study period were similar with each of the 2 allocation strategies (11.5 and $11.7 \mathrm{~kg}$ of $\mathrm{DM} /$ cow per day for group and individual cow, respectively), although the pattern of intake with each treatment differed over time. Concentrate allocation strategy had no effect on either milk yield $(39.3$ and $38.0 \mathrm{~kg} / \mathrm{d}$ for group and individual cow, respectively), milk composition, or milk constituent yield. The milk yield response curves with each treat-
\end{abstract}

Received September 24, 2015.

Accepted February 2, 2016.

${ }^{1}$ Corresponding author: mark.little@afbini.gov.uk ment were largely aligned with the concentrate DMI curves. Cows on the individual cow treatment had a greater range of concentrate DMI and milk yields than those on the group treatment. With the exception of a tendency for cows on the individual cow treatment to lose more body weight to nadir than cows on the group treatment, concentrate allocation strategy had little effect on either body weight or body condition score over the experimental period. Cows on the individual cow treatment had a higher pregnancy rate to first and second service and tended to have a higher 100-d in calf rate than cows on the group treatment. This study demonstrates that concentrate allocation strategy had little effect on overall production performance.

Key words: dairy cow, concentrate allocation strategy, group feeding, individual cow feeding

\section{INTRODUCTION}

Intensive genetic selection for milk production in dairy cows over the last few decades has contributed to increased individual cow milk yields (Ingvartsen and Moyes, 2013). As a result, within days of parturition it is common for dairy cows to produce 10 times more milk than required to satisfy the nutrient requirements of the calf (Grummer et al., 2004). Although genetic selection for milk yields has also resulted in increased feed intakes, intake traits have a lower heritability than milk yield traits (Van Arendonk et al., 1991), with the genetic correlation between milk yield and feed intake ranging from 0.46 to 0.65 (Veerkamp, 1998); consequently, the gap between energy input and output during early lactation is increasing (Oltenacu and Broom, 2010). During early lactation, total energy intake is usually less than the cow's requirements (Bell, 1995), as DMI lags behind peak milk production by 2 to 3 wk. As a result, most dairy cows experience a period of negative energy balance (NEB) in early lactation (Grummer et al., 2004; Ingvartsen, 2006). This induces a catabolic state of body tissue mobilization, which can have negative effects on dairy cow production and fer- 
tility, and increases susceptibility to health disorders, as highlighted in reviews by Roche et al. (2009, 2013).

Achieving high energy intakes in early lactation by offering diets with a high intake potential and with a high energy density per unit of feed has been advocated as a strategy by which to overcome the adverse effects associated with NEB (Ferris et al., 2003). Typically, this is achieved by offering high-quality forages and by increasing concentrate feed levels. With regard the latter, concentrate feed levels have increased considerably on many farms over the last few decades. For example, within the United Kingdom, the amount of concentrate manufactured per cow increased by approximately $75 \%$ between 1990 and 2013 (Wilkinson and Allen, 2015). However, as concentrates are considerably more expensive than conserved forages (Finneran et al., 2012), it is important that they are used efficiently if overall farm profitability is to be increased. Nevertheless, a wide range of concentrate feeding and allocation strategies are adopted in practice. For example, concentrates can be offered on an individual cow basis, whereby each cow within the herd is offered concentrates at a level dictated by her actual milk yield (feed-to-yield). At the other extreme, concentrates can be offered on a group basis, whereby all cows in the herd are offered a single diet that is normally designed to meet the energy requirements of the average cow in the herd or on a flat rate basis where all cows are fed identical amounts of concentrates. Both group and flat-rate strategies take no account of individual cow milk yields and may result in underfeeding of higher-yielding cows and overfeeding of lower-yielding cows.

Several previous studies have examined the effect of concentrate allocation strategy on cow performance. For example, milk production was unaffected when cows with a mean daily milk yield of $25.6 \mathrm{~kg}$ were offered concentrates (mean of $7.6 \mathrm{~kg} / \mathrm{d}$ ) either on a flatrate basis or on an individual cow basis (Gordon, 1982). Additionally, in 2 separate studies (mean daily milk yields of 26.6 and $23.1 \mathrm{~kg}$, respectively), performance was unaffected when concentrates were offered either flat-rate or on an individual cow basis (Taylor and Leaver, 1984a,b). However, these latter studies did not involve a true weekly adjusted feed-to-yield approach within the individual cow strategy, with concentrate feed levels based on milk production potential as assessed at wk 2 postpartum. In an on-farm study, Maltz et al. (1992) compared an individual cow concentrate allocation strategy (which took account of parity, milk yield and milk yield potential, BW change, and feed composition) with a group concentrate allocation strategy. Whereas concentrate intakes were lower with the former treatment, milk yields were higher during lactation 2, but not during lactations 1 and 3. More recently, Lawrence et al. (2015) compared a flat-rate and an individual cow concentrate allocation strategy in a study involving high and low concentrate levels (mean daily milk yield of 25.2 and $23.8 \mathrm{~kg}$, respectively), and demonstrated that neither milk yield nor milk solids yield were affected by concentrate allocation strategy. However, concentrate allocations with the individual cow treatments were based on milk yields during wk 3 to 4 of lactation, rather than a true weekly adjusted feed-to-yield approach where concentrate levels are changed regularly as milk yield varies.

Few studies have compared concentrate allocation strategies with higher-yielding dairy cows (producing approximately $40 \mathrm{~kg}$ of milk/cow per day) offered higher levels of concentrates, as confirmed by a recent review by Hills et al. (2015). In 2 recent exceptions, Purcell et al. (2015, 2016) compared contrasting concentrate allocation strategies in higher-yielding cows. In the latter study, which involved 4 treatments, cows were offered concentrates flat rate (either in a TMR, or via an out-of-parlor feeding system) or using an individual cow strategy (either in a partial mixed ration supplemented with additional concentrates on a feedto-yield basis, or via an out of parlor feeding system on a feed-to-yield basis). Neither milk yield nor milk solids yield were affected by concentrate feeding or allocation strategy. Nevertheless, the individual cow treatments adopted involved allocating cows to 1 of 3 predefined curves (for high-, medium-, and low-yielding cows) based on milk yields during wk 2 to 3 of lactation. In contrast, in the study by Purcell et al. (2015), all cows were offered a basal diet (partial mixed ration) with additional concentrates, then allocated either flat rate through an out-of-parlor feeding system or individually to support individual cow milk yields above that supported by the basal ration. Concentrate levels with the latter treatment were adjusted weekly throughout the experiment. Cows on the flat-rate treatment tended to have lower milk yields, higher milk fat, and higher milk protein concentrations than those on the individual cow treatment. Nevertheless, these latter studies involved relatively small numbers of cows per treatment. Using a different individual cow approach, Maltz et al. (2013) found that allocating concentrates based on individual cow energy balance data improved milk yield and milk components compared with cows offered a single mixed ration treatment, although concentrate intakes were also higher with the former approach.

The current study, which involved a larger number of cows, was designed to examine DMI, milk yield and composition, tissue changes, and fertility of dairy cows allocated concentrates either on an individual cow basis 
or on a group basis. Unlike in previous studies involving higher-yielding cows, the forage component of the diet in the current study comprised grass silage only.

\section{MATERIALS AND METHODS}

\section{Animals and Housing}

This study involved 77 multiparous (parity $=3.2 \pm$ 0.17; mean \pm SEM) Holstein-Friesian dairy cows. Cows had a mean predicted transmitting ability $\left(\mathrm{PTA}_{2015}\right)$ for milk yield and fat plus protein yield of $247( \pm 29.1) \mathrm{kg}$ and $30( \pm 4.5) \mathrm{kg}$, respectively, and a mean profitable lifetime index $\left(\mathrm{PLI}_{2014}\right)$ of $£ 179( \pm 21.1)$. These cows were within the top $1 \%$ of UK genetics in terms of profitable lifetime index. All procedures described in this paper were conducted under and in compliance with the United Kingdom Animals (Scientific Procedures) Act 1986.

Throughout the experiment cows were housed in a freestall cubicle house with concrete flooring that was scraped every $3 \mathrm{~h}$ by an automated system. The cubicle to cow ratio was $\geq 1: 1$ at all times, thus meeting the recommendations of the Farm Animal Welfare Council (1997). Cubicles were fitted with rubber mats and were bedded 3 times each week with sawdust.

\section{Experimental Design, Diets, and Feeding}

From a minimum of $21 \mathrm{~d}$ before the expected calving date, cows were given ad libitum access to grass silage and a dry cow mineral/vitamin mix (Trouw Nutrition, Cheshire, UK) and calcined magnesite (Trouw Nutrition) was mixed with the silage at rates designed to achieve target intakes of 100 and $50 \mathrm{~g} / \mathrm{cow}$ per day, respectively. Cows were moved to a straw-bedded maternity pen approximately 24 to $48 \mathrm{~h}$ before their expected calving, based on physical observations.

Within $24 \mathrm{~h}$ of calving, cows were transferred from the maternity pen to the freestall cubicle house described above and allocated to 1 of 2 concentrate allocation strategies: group or individual cow. Cows on each treatment were balanced for expected calving date, parity, previous lactation 305-d milk yield, BW and BCS at previous lactation drying off, predicted transmitting ability for fat plus protein $(\mathrm{kg})$, number of services during the previous lactation, and calving interval.

Cows on the group treatment were offered a mixed ration comprising grass silage and concentrates (fixed for the study duration at a 50:50 DM ratio) together with chopped straw, the latter included in the mix to achieve a target intake of $0.3 \mathrm{~kg} /$ cow per day. This ration was designed to meet the cows' maintenance energy requirements and to support a mean milk yield of $40 \mathrm{~kg} / \mathrm{cow}$ per day over the 20-wk study, assuming an average BW loss of $0.5 \mathrm{~kg} / \mathrm{cow}$ per day over the experimental period. Ration formulation was based on the equations contained within Agnew et al. (2004), the current UK dairy cow feed rationing system, and the $\mathrm{ME}$ and intake potential of the grass silage offered, as determined by near-infrared reflectance spectroscopy. Cows on the individual cow treatment were offered a basal mixed ration ad libitum, comprising grass silage plus concentrates, the latter included in the mix to achieve an average intake of $6.0 \mathrm{~kg}$ concentrate/cow per day. Chopped straw was also included in this mix to achieve a target intake of $0.3 \mathrm{~kg} / \mathrm{cow}$ per day. Based on the equations of Agnew et al. (2004) and the estimated intake potential and nutritive value of the silage offered, this basal ration was initially estimated to sustain the maintenance energy requirements of the cow, plus a milk yield of $27 \mathrm{~kg} /$ cow per day, which was revised to $24 \mathrm{~kg} /$ cow per day based on actual DMI data 8 wk into the study period, as is normal practice on farms adopting similar feeding strategies. This change was implemented at a time when $61 \%$ of the herd had calved, with these cows being a mean of 31 DIM at the time of the change. Thus, approximately $5 \%$ of total cow days between wk 3 and 20 were completed before this change in diet. In addition to this basal ration, cows on this treatment were offered additional concentrates via an out-of-parlor feeding system comprising 6 feeding stations. This feeding system allowed the preprogrammed daily concentrate allocation to be spread across 6 equal time windows throughout each 24 -h period. From d 1 postcalving, these additional concentrates were increased in $0.25-\mathrm{kg} / \mathrm{d}$ increments, so that cows were offered $5.25 \mathrm{~kg}$ of concentrate daily via the out-of-parlor feeding system at d 21 postcalving. From d 21 onwards, this additional concentrate changed from being offered at a fixed predetermined level for all cows, to a feedto-yield basis. Feed levels were adjusted weekly, based on the mean milk yield during the previous 7 -d period, with concentrates offered at a feed rate of $0.45 \mathrm{~kg}$ concentrate for each kilogram of milk produced above what the basal diet was assumed to sustain. In addition to the diets described above, all cows on both treatments were offered an additional $1.0 \mathrm{~kg}$ of concentrate daily via an in-parlor concentrate feeding system, $0.5 \mathrm{~kg}$ at each milking.

A common concentrate was offered with both treatments, in the mixed diets (in the form of a meal) and via the in-parlor and out-of-parlor feeding system (in the form of a pellet). The ingredient composition of the concentrate offered $(\mathrm{g} / \mathrm{kg}$ fresh basis) was as follows: maize, 215.5; wheat, 160; wheat feed, 60; sugar beet pulp, 100; distillers grains, 50; corn gluten, 40; soy hulls, 140; soybean meal, 80; Sopralin (Trouw Nutri- 
tion), 30; rapeseed meal, 40; lime flour, 7; salt, 7.5, calcined magnesite (Trouw Nutrition), 3; Molaferm (United Molasses, Belfast, UK) 50; palm oil, 8; Acid buf (Celtic Sea Minerals, Cork, Ireland), 8; mineral/ vitamin mix (Superdairy, Trouw Nutrition), 4; and Actisaf (Lesaffre, Shannon, Ireland), 0.4. Cows remained on their treatments until d 140 of lactation.

The grass silage offered throughout the experiment was produced from a primary growth herbage harvested from predominantly perennial ryegrass-based swards (harvest dates, May 22 to 30), and ensiled following a 24- to 48-h period of field wilting. Rations were prepared using a complete diet mixer wagon (Redrock Varicut, Redrock, UK), with the silage, concentrates, and straw components of each diet mixed for approximately $6 \mathrm{~min}$. Following mixing, the rations for each treatment were transferred directly from the mixer wagon to feed-boxes mounted on weigh cells, access to which was controlled by a Calan Gate feeding system (American Calan Inc., Northwood, NH) linked to an electronic identification system, thus enabling individual cow intakes to be recorded daily. Cows within each treatment group were able to feed from several feed boxes, whereas a feed box-to-cow ratio of $\geq 1: 3$ was maintained at all times. Both diets were offered ad libitum at $107 \%$ of the previous day's intake. Uneaten ration was removed daily at approximately $0800 \mathrm{~h}$, whereas the fresh ration was offered between 0900 and $1000 \mathrm{~h}$.

\section{Feed Analysis}

The grass silage offered was sampled daily and analyzed for oven DM content $\left(85^{\circ} \mathrm{C}\right)$. Samples of the dried silage were collected twice weekly and bulked over each 2-wk period, with these dried samples analyzed for concentrations of NDF and ADF (Cushnahan and Gordon, 1995). In addition, a sample of each of the fresh silages offered was analyzed weekly by near-infrared reflectance spectroscopy for ME concentration (Park et al., 1998), whereas a second fresh sample was analyzed for gross energy concentration (Porter, 1992), pH, nitrogen and ammonia-nitrogen concentrations (Steen, 1989), and for lactic acid and VFA concentrations (Porter and Murray, 2001). Volatility coefficients (Porter and Murray, 2001) were used to convert the oven DM contents of the grass silages offered to a volatile-corrected DM basis.

The concentrates offered were sampled weekly, with samples bulked for each 2-wk period. A subsample was subsequently dried at $100^{\circ} \mathrm{C}$ and its oven $\mathrm{DM}$ content determined, with the dried sample subsequently analyzed for nitrogen, ADF, NDF, and gross energy concentrations (Cushnahan and Gordon, 1995). A second subsample was dried at $60^{\circ} \mathrm{C}$ and analyzed for starch using a Megazyme kit (Megazyme International Ireland, Bray, Ireland; McCleary et al., 1994).

\section{Measurements of Cow Performance}

Food intakes for each individual cow were recorded daily using the intake-recording system described earlier. Cows were milked twice daily, between 0530 and 0700 as well as 1530 and $1700 \mathrm{~h}$, through a 50-point rotary milking parlor. Individual cow milk yields were automatically recorded at each milking and a mean daily milk yield was calculated for each cow on a weekly basis. Milk yields were not recorded during the first 5 $\mathrm{d}$ after calving, and these were subsequently estimated by plotting a linear response through milk yields for $\mathrm{d}$ 6 to 15 postcalving and interpolating back for $\mathrm{d} 1$ to 5. Milk samples were obtained weekly from 2 consecutive milkings (a.m. and p.m.), a preservative tablet was added (Broad Spectrum Microtabs II, D and F Control Systems, Advanced Instruments Inc., Norwood, MA), and samples were stored at $4^{\circ} \mathrm{C}$ until analyzed. These samples were analyzed weekly for fat, protein, and lactose content using an infrared milk analyzer (Milkoscan, model FT 120, Foss UK Ltd., Warrington, UK) and a weighted milk composition was subsequently calculated for each sampling occasion. In addition, a single milk sample was collected from each cow on 2 occasions each week (p.m.) until $80 \mathrm{~d}$ postcalving for progesterone analysis. Samples were preserved and stored as above (for a maximum of $3 \mathrm{wk}$ ), with progesterone concentrations subsequently determined using a competitive ELISA kit (Ridgeway Science Ltd., Gloucestershire, UK), with the assay based on the method of Sauer et al. (1986). Cow BW were recorded twice daily (using an automatic weigh scale) from calving until the end of the study. Body condition scores were recorded fortnightly using a 1-to-5 scale (Edmonson et al., 1989). All estrus events were recorded for the duration of the study. After the 42-d voluntary waiting period, cows were inseminated $12 \mathrm{~h}$ after visual observation of estrus. With the exception of cows treated for uterine infections and follicular cysts, no other reproductive treatments were given until after d 80 of lactation. Pregnancy was diagnosed via an ultrasound scan conducted by a veterinary surgeon at d 30 and 60 postinsemination.

The mean daily ME requirements and balances for each cow were calculated using the equations of Agnew et al. (2004), where daily mean energy balance (MJ/ cow per day) was determined using the equation:

$$
\begin{aligned}
& \text { Mean energy balance }= \\
& {\left[\left(\mathrm{ME}_{\text {main }+ \text { milk }} \times \mathrm{BW}^{0.75}\right)+\left(\frac{0.0013 \times \mathrm{BW}}{K_{m}}\right)-10\right]-\mathrm{ME}_{i},}
\end{aligned}
$$


where $\mathrm{ME}_{\text {main-milk }}$ is the $\mathrm{ME}$ required for maintenance and milk production ( $\mathrm{MJ} / \mathrm{kg}$ of metabolic weight), $\mathrm{BW}^{0.75}$ is the metabolic BW, $K_{m}$ is the efficiency of utilization of ME for activity (calculated as $0.35 \times \mathrm{ME} /$ gross energy +0.503$)$, and $\mathrm{ME}_{i}$ is the $\mathrm{ME}$ intake $(\mathrm{MJ} /$ cow per day). Data for mean daily milk yield, milk fat, protein and lactose concentrations, and mean BW were used in the calculations for the energy balance variables.

\section{Fecal Consistency Scoring and Fecal Fiber Measurements}

At d 30, 60, and $90( \pm 3 \mathrm{~d})$ postcalving, fecal consistency scoring was carried out as described by Zaaijer and Noordhuizen (2003) using a 1-to-5 scale, and on each occasion a fecal sample (approximately $500 \mathrm{~g}$ fresh) was collected from each cow. Scoring and sampling was undertaken before morning feeding (between 0800 and $0900 \mathrm{~h}$ ) when cows were in the cubicle house. Approximately $400 \mathrm{~g}$ of fresh feces (380-420 g) was weighed out and placed in the top tray of a digestion analyzer sieve (Nasco, Fort Atkinson, WI). After gentle washing for $3 \mathrm{~min}$, all material remaining within the top sieve (4.8-mm holes) was placed in a preweighed aluminum foil tray. The process was repeated for another $3 \mathrm{~min}$ on the material present in the middle sieve (3.2-mm holes) and bottom sieve (1.6-mm holes). The sieved samples were dried at $85^{\circ} \mathrm{C}$ for $18 \mathrm{~h}$ and the dry weight was determined to the nearest $0.001 \mathrm{~g}$. The content of each tray was calculated as a proportion of total DM recovered from the all trays.

\section{Statistical Analysis}

Five cows were removed from the experiment for reasons not associated with the treatments and their data excluded from the statistical analysis, leaving 36 cows on each treatment. Data were analyzed using GenStat Version 16.2 (VSN International, Oxford, UK). The management regimens imposed necessitated that cows on the individual cow treatment were subject to a common management regimen until d 21 postcalving before moving to the yield-based individual cow strategy. However, this was considered an integral part of the treatment design and, consequently, data for the entire period from calving until wk 20 were included in the statistical analysis. Data describing DMI, milk yield, milk constituents, milk constituent yield, BW, BCS, mean daily energy balance, progesterone parameters, and the percentage of fecal residues trapped in different mesh sizes were analyzed using ANOVA. Where significant in the model, appropriate pre-experimental variables were included as co-variates when analyzing corresponding dependent variables. Milk yield was analyzed with the addition of previous lactation 305-d milk yield in the model. Similarly, milk constituent fat, milk constituent protein, BW, and BCS were analyzed with the addition of previous lactation fat composition, previous lactation protein composition, pre-experimental $\mathrm{BW}$, and pre-experimental BCS, respectively, in the model. Weekly data for mean daily concentrate and silage DMI, mean daily milk yield, and mean daily energy balance were analyzed using repeated measures REML analysis. The mixed model used included the following terms as fixed effects: treatment + week + treatment $\times$ week. Cow $\times$ week was included in the random model, to which a power model (city block metric) covariance structure was applied. Mean daily milk yield was analyzed as above, except that previous lactation 305-d milk yield was also included in the mixed model. Data describing fertility outcomes and fertility treatments were analyzed using generalized linear model regression analysis with the logit link function. The model included treatment as a term, and significance was identified using chi-squared. Data describing fecal consistency score were analyzed using ordinal logical regression using the logit link function, with significance was identified used chi-squared. Correlations of total, silage, and concentrate DMI and ME intake with mean daily milk yields of individual cows, and between mean daily energy balance and mean daily milk yields of individual cows, were undertaken using simple linear regression analysis within each treatment.

\section{RESULTS}

The grass silage offered was good quality (oven DM, volatile-corrected oven $\mathrm{DM}, \mathrm{CP}, \mathrm{ADF}, \mathrm{NDF}$, gross energy, and ME of $298 \mathrm{~g} / \mathrm{kg}, 314 \mathrm{~g} / \mathrm{kg}, 159 \mathrm{~g} / \mathrm{kg}$ of DM, $291 \mathrm{~g} / \mathrm{kg}$ of DM, $486 \mathrm{~g} / \mathrm{kg}$ of DM, $18.3 \mathrm{MJ} / \mathrm{kg}$ of DM, and $11.6 \mathrm{MJ} / \mathrm{kg}$ of DM, respectively) and was well fermented ( $\mathrm{pH}$, ammonia nitrogen, lactic acid, and acetic acid of $3.83,78 \mathrm{~g} / \mathrm{kg}$ of total nitrogen, $126 \mathrm{~g} / \mathrm{kg}$ of DM, and $19.2 \mathrm{~g} / \mathrm{kg}$ of $\mathrm{DM}$, respectively). The concentrate offered had an oven DM, CP, ADF, NDF, gross energy, and ME content (the latter estimated using standard book values) of $872 \mathrm{~g} / \mathrm{kg}, 180 \mathrm{~g} / \mathrm{kg}, 152 \mathrm{~g} / \mathrm{kg}$ of DM, $303 \mathrm{~g} / \mathrm{kg}$ of DM, $17.9 \mathrm{MJ} / \mathrm{kg}$ of DM, and $11.2 \mathrm{MJ} / \mathrm{kg}$ of DM. The mean $\mathrm{ME}$ and $\mathrm{CP}$ of the total ration offered with the group treatment was $11.4 \mathrm{MJ} / \mathrm{kg}$ of $\mathrm{DM}$ and $170 \mathrm{~g} / \mathrm{kg}$ of DM, respectively. The mean ME and CP of the individual cow treatment total ration was $11.4 \mathrm{MJ} /$ $\mathrm{kg}$ of $\mathrm{DM}$ and $170 \mathrm{~g} / \mathrm{kg}$ of DM, respectively, of which the basal ration was $11.4 \mathrm{MJ} / \mathrm{kg}$ of $\mathrm{DM}$ and $164 \mathrm{~g} / \mathrm{kg}$ of DM, respectively.

Cows on the group treatment tended to have a greater $(P=0.095)$ silage DMI than those on the individual 
Table 1. Effects of concentrate allocation strategy on DMI, milk yield, milk constituents, and milk constituent yield during the first $140 \mathrm{~d}$ of lactation

\begin{tabular}{|c|c|c|c|c|}
\hline \multirow[b]{2}{*}{ Item } & \multicolumn{2}{|c|}{ Concentrate allocation strategy } & \multirow[b]{2}{*}{$\mathrm{SED}^{1}$} & \multirow[b]{2}{*}{$P$-value } \\
\hline & Individual cow & Group & & \\
\hline \multicolumn{5}{|l|}{ DMI (kg/d) } \\
\hline Concentrate & 11.7 & 11.5 & 0.25 & 0.714 \\
\hline Silage & 10.3 & 10.6 & 0.14 & 0.095 \\
\hline Total $^{2}$ & 22.2 & 22.4 & 0.31 & 0.773 \\
\hline Milk yield (kg/d) & 38.0 & 39.3 & 0.95 & 0.326 \\
\hline \multicolumn{5}{|c|}{ Milk constituent (g/kg) } \\
\hline Fat & 42.8 & 42.9 & 0.46 & 0.882 \\
\hline Protein & 32.9 & 32.4 & 0.31 & 0.258 \\
\hline Lactose & 46.4 & 46.4 & 0.24 & 0.878 \\
\hline \multicolumn{5}{|c|}{ Milk constituent yield (kg/d) } \\
\hline Fat & 1.7 & 1.8 & 0.05 & 0.257 \\
\hline Protein & 1.3 & 1.3 & 0.03 & 0.258 \\
\hline Fat + protein & 3.0 & 3.1 & 0.09 & 0.420 \\
\hline
\end{tabular}

${ }^{1} \mathrm{SED}=$ standard error of the difference.

${ }^{2}$ Total DMI includes approximately $0.3 \mathrm{~kg}$ of straw/cow per day.

cow treatment, although concentrate DMI $(P=0.714)$ and total DMI $(P=0.773)$ were unaffected by treatment (Table 1). Cows on the individual cow treatment had a greater range of concentrate DMI than cows on the group treatment $(\mathrm{CV}=23$ and $11 \%$, respectively, at wk 8 postcalving; and 22 and $10 \%$, respectively, at wk 20 postcalving).

Concentrate allocation strategy had no effect $(P=$ $0.326)$ on daily milk yield, milk fat $(P=0.882)$, protein $(P=0.258)$, or lactose $(P=0.878)$ concentrations, or on milk fat $(P=0.257)$, protein $(P=0.258)$, or fat and protein $(P=0.420)$ yields (Table 1$)$. Cows on the individual cow treatment had a greater range of milk yields than cows on the group treatment $(\mathrm{CV}=21$ and $14 \%$, respectively). Cows in the upper quartile of milk yield within the individual cow treatment produced milk with a lower milk fat concentration than the mean of the remaining cows on this treatment ( 39.3 vs. 44.5 $\mathrm{g} / \mathrm{kg}$, respectively, a difference of $5.2 \mathrm{~g} / \mathrm{kg}$ ), whereas respective values for the group treatment were 40.4, 43.6 , and $3.2 \mathrm{~g} / \mathrm{kg}$.

Concentrate allocation strategy had no effect on mean $(P=0.782) \mathrm{BW}$ or BW at $\mathrm{d} 7(P=0.261), 70$ $(P=0.897), 140(P=0.727)$, or nadir $(P=0.954)$, nor days to nadir $\mathrm{BW}(P=0.421)$; however, cows on the individual cow treatment tended $(P=0.088)$ to have a greater BW loss to nadir than cows on the group treatment. No effect of concentrate allocation strategy was noted on mean $(P=0.618) \mathrm{BCS}$ or BCS at $\mathrm{d} 7(P$ $=0.573), 70(P=0.495)$, or $140(P=0.812)$, and no effect $(P=0.426)$ on mean daily energy balance was observed either (Table 2).

Table 2. Effects of concentrate allocation strategy on cow BW and BCS parameters, and on mean daily energy balance during the first $140 \mathrm{~d}$ of lactation

\begin{tabular}{|c|c|c|c|c|}
\hline \multirow[b]{2}{*}{ Item } & \multicolumn{2}{|c|}{ Concentrate allocation strategy } & \multirow[b]{2}{*}{$\mathrm{SED}^{1}$} & \multirow[b]{2}{*}{$P$-value } \\
\hline & Individual cow & Group & & \\
\hline \multicolumn{5}{|l|}{ BW (kg) } \\
\hline Mean & 623 & 621 & 4.9 & 0.782 \\
\hline At d 7 & 637 & 627 & 8.7 & 0.261 \\
\hline At d 70 & 619 & 618 & 7.6 & 0.897 \\
\hline At d 140 & 631 & 628 & 6.1 & 0.727 \\
\hline At nadir & 594 & 594 & 7.7 & 0.954 \\
\hline Loss to nadir & 43 & 33 & 4.2 & 0.088 \\
\hline Days to nadir & 60 & 52 & 9.6 & 0.421 \\
\hline \multicolumn{5}{|l|}{$\mathrm{BCS}$} \\
\hline Mean & 2.5 & 2.5 & 0.04 & 0.618 \\
\hline At d 7 & 2.6 & 2.6 & 0.05 & 0.573 \\
\hline At d 70 & 2.5 & 2.5 & 0.05 & 0.495 \\
\hline At d 140 & 2.4 & 2.4 & 0.05 & 0.812 \\
\hline Mean daily energy balance (MJ/cow per day) & -21.4 & -25.5 & 5.26 & 0.426 \\
\hline
\end{tabular}

${ }^{1} \mathrm{SED}=$ standard error of the difference. 
In view of the very different concentrate allocation strategies adapted, changes to concentrate DM, silage DM, milk yield, and energy balance were also examined over the 20-wk experimental period (Figure 1a-d, respectively). When weekly data were analyzed using repeated measure analysis, cows on the individual cow treatment tended to have a greater $(P=0.069)$ concentrate DMI and lower silage DMI $(P=0.059)$ than those in the group treatment. Both concentrate DMI and silage DMI changed over the 20-wk experimental period (Time: $P<0.001$ ), and a treatment $\times$ time interaction $(P=0.001, P=0.018$, respectively) was noted for both variables (Figures 1a and b, respectively). Concentrate allocation strategy had no effect $(P=0.113)$ on mean daily milk yield; however, mean daily milk yield varied over time $(P<0.001)$, and a treatment $\times$ time interaction $(P=0.019)$ was observed for weekly milk yield (Figure 1c). Although we found no effect $(P=0.356)$ of concentrate allocation strategy on mean daily energy balance, mean daily energy balance changed (time: $P$ $<0.001$ ) over the 20 -wk experimental period (Figure 1d) and no treatment $\times$ time interaction was noted $(P$ $=0.674)$.

When total DMI, silage DMI, and concentrate DMI of each individual cow was plotted against their mean daily milk yields, a linear increase in total $(P<0.001)$ and concentrate $(P<0.001)$ DMI and a linear decrease in silage $(P=0.014)$ DMI was observed, with increasing milk yield for cows on the individual cow treatment (Figure 2a). In contrast, we found a linear increase in concentrate $(P=0.041)$, silage $(P=0.029)$, and total $(P=0.028)$ DMI for cows on the group treatment with increasing milk yields (Figure $2 \mathrm{~b}$ ). The silage-toconcentrate ratio of the diet remained constant with the group treatment (approximately 50:50), whereas cows on the individual cow treatment had a wide range of ratios (56:44 and 32:68 with the lowest- and highestyielding cows at wk 8 postcalving, respectively). Figure 2a demonstrates substitution with the individual cow treatment, with silage DMI decreasing by $0.05 \mathrm{~kg}$ with every $1.0-\mathrm{kg}$ increase in milk yield (equal to a $0.19-\mathrm{kg}$ decrease in silage $\mathrm{DMI} / \mathrm{kg}$ of concentrate DMI). The (a)

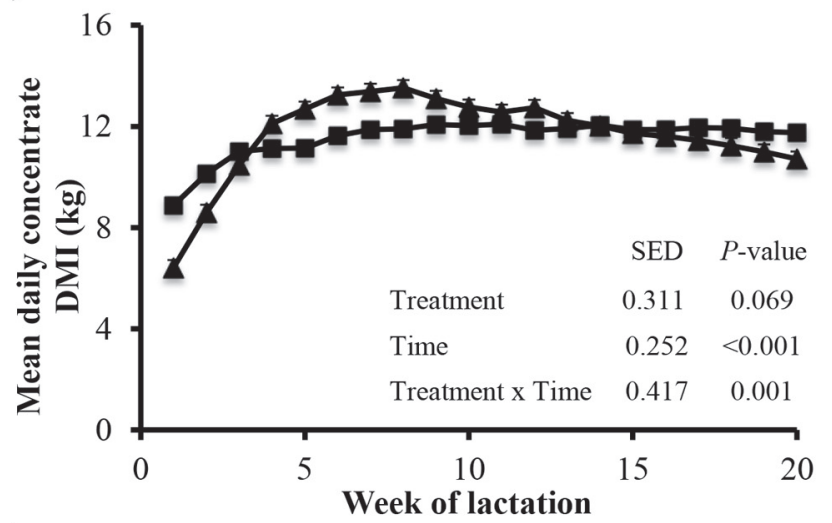

(c)

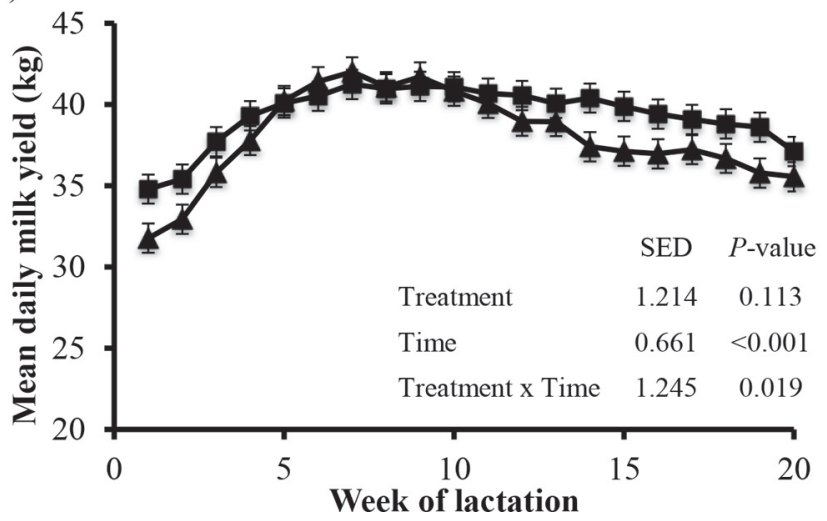

(b)

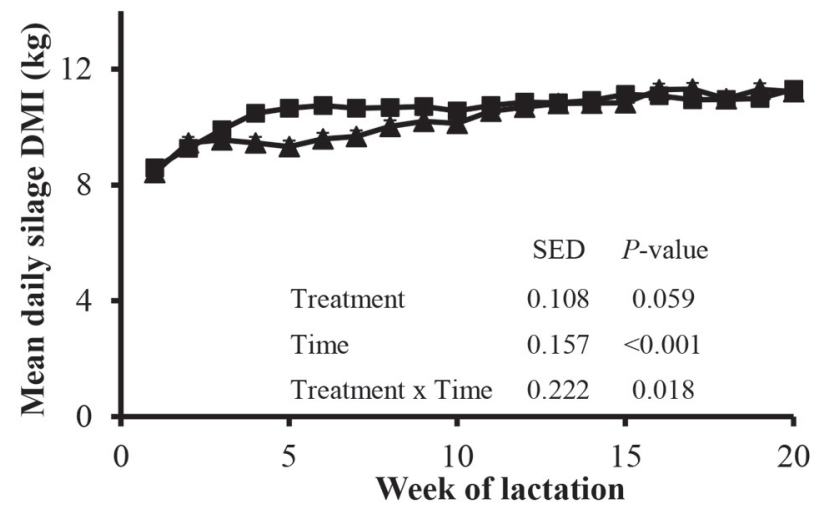

(d)

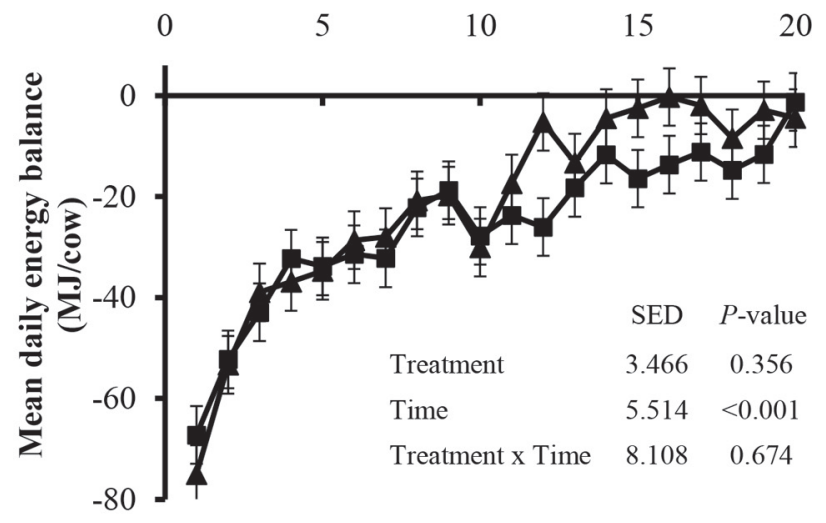

Figure 1. Effects of concentrate allocation strategy on (a) mean daily concentrate DMI, (b) mean daily silage DMI, (c) mean daily milk yield, and (d) mean daily energy balance. $\boldsymbol{\Delta}=$ individual cow, $\mathbf{\square}=$ group; error bars represent the standard error of the mean. SED $=$ standard error of the difference. 
(a)

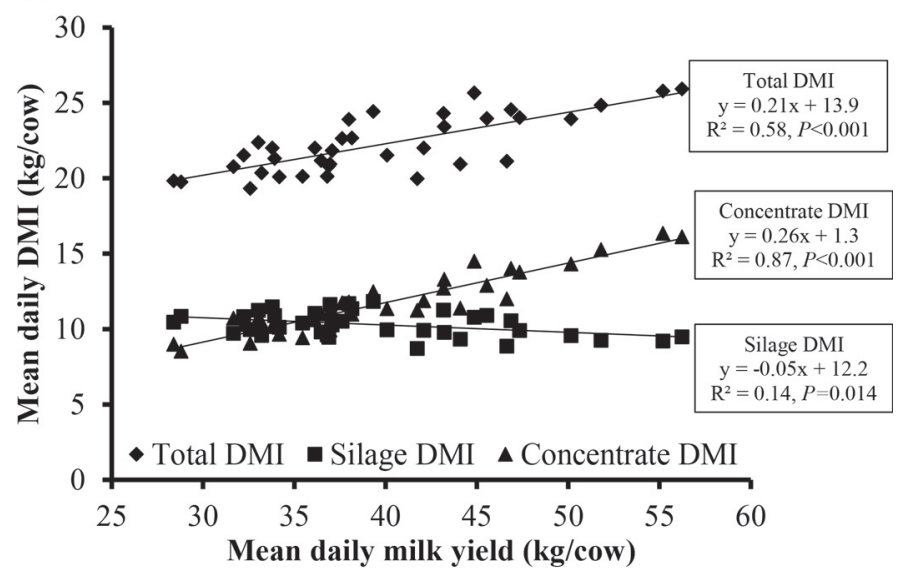

(b)

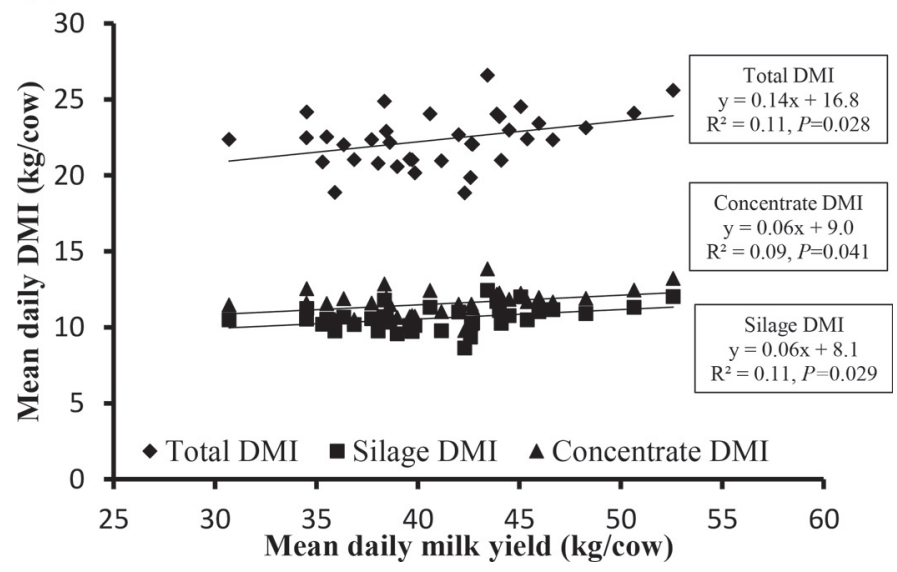

Figure 2. Linear relationships between mean daily DMI and milk yields for cows managed on (a) individual cow and (b) group concentrate allocation strategies. Total DMI value includes straw at approximately $0.3 \mathrm{~kg} / \mathrm{cow}$ per day.

linear relationship between mean total ME intake (MEI) and mean daily milk yield is described as, $\mathrm{MEI}=2.54$ $\times$ milk yield $+154.2\left(\mathrm{R}^{2}=0.61, P<0.001\right)$ and MEI $=1.46 \times$ milk yield $+195.3\left(\mathrm{R}^{2}=0.11, P<0.028\right)$ for the individual cow and group treatments, respectively. When the relationships between mean daily energy balance and mean daily milk yields were examined, a linear decrease $(P<0.001)$ in mean daily energy balance was observed as milk yields increased for both the individual cow and group treatments (Figure 3), with the slope of the lines being -2.07 and -3.39 for the individual cow and group treatments, respectively

Concentrate allocation strategy had no effect on day to onset of corpus luteal activity $(P=0.873)$, the percentage of cows showing corpus luteal activity before d $42(P=0.323)$ and 70 postcalving $(P=0.237)$, maximum progesterone concentration during with the first corpus luteal ( $P=0.145)$, pregnancy rate to first service $(P=0.251)$, or the percentage of cows with GnRH treatments $(P=0.690)$. The incidence of prostaglandin treatments were equally distributed for both treatments, with a statistical analysis of the data not possible. However, cows on the individual cow treatment had a higher pregnancy rate to first and second service $(P=0.014)$ and tended to have a higher $100-\mathrm{d}$ in-calf rate $(P=0.071)$ and lower percentage of cows with progesterone treatments $(P=0.068)$ than cows on the group treatment (Table 3 ).

Concentrate allocation strategy had no effect on fecal consistency scores, with the probabilities of fecal samples having a consistency score of 1 to $2,2.5,3$, and $>3$ being, respectively, $0.21,0.14,0.55$, and 0.09 for the individual cow treatment and $0.26,0.16,0.50$, and 0.07 for the group treatment at d $30(P=0.502) ; 0.16$, $0.25,0.47$, and 0.12 for the individual cow treatment and $0.12,0.22,0.50$, and 0.15 for the group treatment at $\mathrm{d} 60(P=0.554)$; and $0.21,0.14,0.51$, and 0.14 for the individual cow treatment and $0.15,0.11,0.54$,

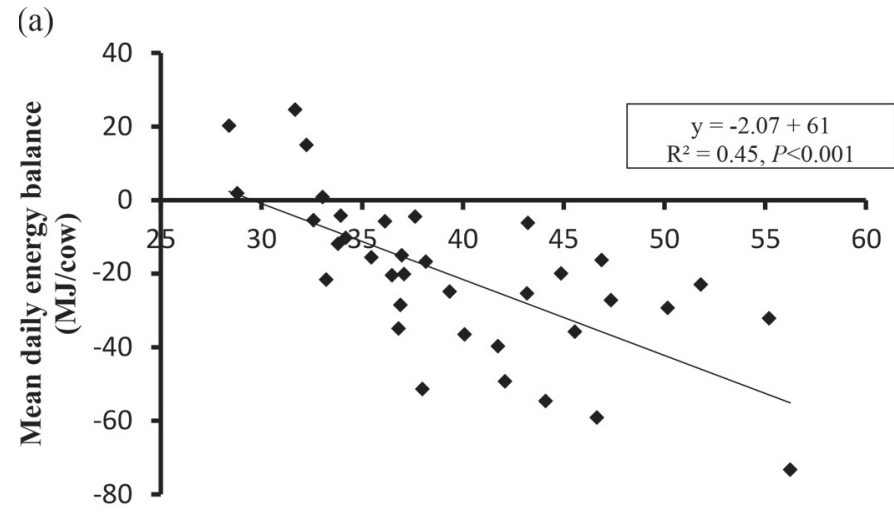

Mean daily milk yield (kg/cow)

(b)

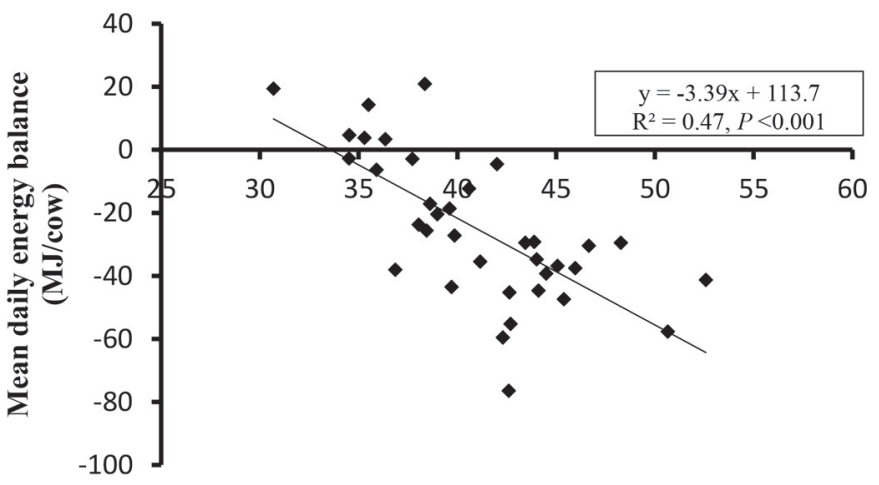

Mean daily milk yield (kg/cow)

Figure 3. Linear relationships between mean daily energy balance and mean daily milk yields for cows managed on (a) individual cow and (b) group concentrate allocation strategies. 
Table 3. Effects of concentrate allocation strategy on parameters derived from milk progesterone values, and on fertility outcomes and fertility treatments

\begin{tabular}{|c|c|c|c|c|}
\hline Item & \multicolumn{2}{|c|}{ Concentrate allocation strategy } & $\mathrm{SED}^{1}$ & $P$-value \\
\hline Onset of corpus luteal activity (d) & 31 & 31 & 2.4 & 0.873 \\
\hline Corpus luteal activity $<42 \mathrm{~d}^{2}(\%$ of cows) & 81 & 89 & 5.9 & 0.323 \\
\hline Corpus luteal activity $<70 \mathrm{~d}^{2}$ (\% of cows) & 97 & 100 & 1.3 & 0.237 \\
\hline Maximum progesterone concentration during the first corpus luteum $(\mathrm{ng} / \mathrm{mL})$ & 12.9 & 10.6 & 1.11 & 0.145 \\
\hline Pregnancy rate to first and second service (\% of cows) & 80.0 & 50.0 & 8.22 & 0.014 \\
\hline $100 \mathrm{~d}$ in-calf $\operatorname{rate}^{2}(\%$ of cows $)$ & 76.7 & 54.8 & 8.32 & 0.071 \\
\hline \multicolumn{5}{|l|}{ Fertility treatment ( $\%$ of cows treated with) } \\
\hline Progesterone & 6 & 19 & 5.2 & 0.068 \\
\hline Prostaglandin & 33 & 33 & 7.8 & ${ }_{3}^{3}$ \\
\hline GnRH & 11 & 8 & 4.8 & 0.690 \\
\hline
\end{tabular}

${ }^{1} \mathrm{SED}=$ standard error of the difference.

${ }^{2}$ Relative to calving date.

${ }^{3}$ No analysis possible as response is identical for both treatments.

and 0.20 for the group treatment at $\mathrm{d} 90(P=0.418)$. Concentrate allocation strategy had no effect on fecal residue retained by sieves with $4.8-(P=0.748), 3.2-$ $(P=0.739)$, and $1.6-\mathrm{mm}(P=0.832)$ diameter holes at d 30 (percentage retained being 25, 13, and $62 \%$ for the individual cow and 24, 14, and $63 \%$ for the group treatment, respectively) and at d 60 postcalving $(P=0.998,0.140$, and 0.554 for the $4.8-, 3.6$, and 1.6-mm diameter holes), with the percentage retained being 24,14 , and $62 \%$ for the individual cow and 24 , 12 , and $64 \%$ for the group treatment, respectively. At d 90 postcalving, cows on the group treatment had a smaller proportion of fecal residues retained by the 4.8$\mathrm{mm}$ sieve $(P=0.013)$ and a larger proportion by the $1.6-\mathrm{mm}$ sieve $(P=0.010)$ than for the individual cow treatment, with no difference for the $3.2-\mathrm{mm}$ sieve $(P=$ $0.813)$; the percentage retained was 31,15 , and $54 \%$ for the individual cow and 21,15 , and $64 \%$ for the group treatment, respectively.

\section{DISCUSSION}

Diverse concentrate allocation strategies have been adopted on farms, ranging from systems where all cows are offered a single diet irrespective of level of performance to those where concentrates are targeted to individual cows depending on each cow's milk yield. Although such different approaches might be expected to result in different levels of performance, evidence that this is actually the case, especially with higheryielding cows (approximately $40 \mathrm{~kg}$ milk/cow per day), is limited. The current study was therefore designed to examine this issue.

\section{DMI}

Whereas the 2 concentrate allocation strategies adopted were very different, the mean daily concentrate DMI over the study period was similar, being 11.7 and $11.5 \mathrm{~kg} /$ cow per day with the individual cow and group treatments, respectively, a difference of only $0.2 \mathrm{~kg} /$ cow per day. However, Figure 1a demonstrates that the mean concentrate DMI with each of the 2 treatments differed over time, with a treatment $\times$ time interaction observed. Whereas cows on the group treatment had a relatively flat concentrate intake curve, mean concentrate intake with the individual cow treatment increased over the first 8 wk postcalving, before declining throughout the remainder of the study period. In addition, Figure 1a fails to demonstrate the much greater range in concentrate intakes (as evidenced by the CV) between cows on the individual cow treatment compared with the group treatment. The absence of an effect of concentrate allocation strategy on mean silage DMI is in agreement with the findings of Lawrence et al. (2015) and Moisey and Leaver (1985). As with concentrate DMI, a time $\times$ treatment interaction was noted for silage intakes, with silage intakes with the individual cow treatment tending to be lower in early lactation at the time when concentrate intakes were highest with this treatment, reflecting substitution of silage by concentrates. Despite very different trends in concentrate and silage DMI, concentrate allocation strategy had no effect on total DMI over the experimental period, in agreement with previous studies that compared individual cow and flat-rate concentrate allocation strategies (Taylor and Leaver, 1984a,b; Moisey and Leaver, 1985; Lawrence et al., 2015). 


\section{Milk Production and Milk Composition}

The absence of an effect of concentrate allocation strategy on mean daily milk yield over the experimental period can be explained in part by the absence of an effect of treatment on mean concentrate, silage, and total DMI. Similarly, milk composition was unaffected by treatment. These outcomes agree with results of previous studies (Taylor and Leaver, 1984a,b; Moisey and Leaver, 1985; Lawrence et al., 2015), which involved lower-yielding cows (range $=21.8-29.3 \mathrm{~kg} / \mathrm{d}$ ) and a study involving cows with a mean milk yield of 40.3 $\mathrm{kg} / \mathrm{d}$ (Purcell et al., 2016). However, as highlighted previously, these studies did not involve a true feed-toyield approach with the individual cow strategies, as cows were allocated concentrates based on milk yields shortly after calving. In contrast, in a study involving cows with a mean milk yield of $38.0 \mathrm{~kg} / \mathrm{d}$ (Purcell et al., 2015), a tendency was noted for cows offered concentrates using a true feed-to-yield approach to produce more milk, albeit with a lower fat and protein content, than cows offered concentrates flat rate. Nevertheless, the overall effect in Purcell et al. (2015) was that fat plus protein yield was unaffected by concentrate allocation strategy.

Whereas concentrate allocation strategy had no effect on mean milk yield over the entire experiment, Figure 1c highlights that the mean milk yields with each of the 2 treatments differed over time $(P<0.001)$, with a treatment $\times$ time interaction $(P=0.019)$ observed. Although cows on the group treatment had a relatively flat lactation curve, the mean milk yield with the individual cow treatment increased over the first $7 \mathrm{wk}$ postcalving and then declined throughout the remainder of the study period, with these responses largely aligned with the concentrate intake curves discussed earlier. In addition, cows on the individual cow treatment had a greater range of milk yields than cows on the group treatment, in agreement with the findings of Lawrence et al. (2015). The wider range in both milk yield and concentrate intakes with the individual cow treatment compared with the group treatment is highlighted in Figure 2.

The results of the current study are largely in agreement with the findings of similar studies involving grazing cows. For example, Leaver (1988) and Dale et al. (2016) found concentrate allocation strategy to have no effect on milk production or composition. However, when grazing cows were offered a restricted herbage allowance (García et al., 2007), milk yields were increased when concentrates were offered on an individual cow basis. In a review of studies examining concentrate allocation strategies for grazing cows, Hills et al. (2015) suggested that when herbage allowance is restricted, individual cow allocation strategies have the potential to exploit the milk yield potential of higher-yielding cows. Nevertheless, when cows are housed and offered diets based on conserved forages, restricted access to forage is not normally advocated or practiced.

When considering the absence of a milk yield response to the 2 concentrate allocation strategies examined, it is important to note that cows on this experiment had a relatively narrow range in calving dates (118 d); as such, they were at a relatively similar stage of lactation during the experimental period. However, in practice, most farms operate a much wider range of calving dates (often year-round calving), meaning that herds often comprise cows ranging in lactation stage from early to late lactation. In this scenario it is likely that the use of a single-group feeding approach might result in overfeeding of cows in late-lactation cows; as such, cows should be grouped according to stage of lactation.

\section{Relationships Between DMI and Milk Yield}

The relationships between DMI (concentrates, silage, and total) and milk yield (Figure 2) highlight clear differences between allocation strategies. The larger DMI response with the individual cow treatment (total DMI increased by $0.21 \mathrm{~kg} / \mathrm{kg}$ increase in milk yield, compared with $0.14 \mathrm{~kg} / \mathrm{kg}$ increase in milk yield with the group treatment) can be attributed to the fact that a significant proportion of the concentrate is offered separately from the silage, thus allowing higher-yielding cows to consume additional concentrates without having to consume additional forage. In contrast, with the mixed ration offered with the group treatment, higher-yielding cows had to consume additional silage to increase their concentrate intake, thus limiting the total DMI response. This is further demonstrated by cows on the individual cow treatment increasing their concentrate DMI by a $0.26 \mathrm{~kg} / \mathrm{kg}$ increase in milk yield, compared with a $0.06 \mathrm{~kg} / \mathrm{kg}$ increase in milk yield with the group treatment.

The low substitution rate demonstrated in Figure 2a is in contrast to the outcome of many traditional studies in which substitution rates increased considerably (range $=0.44-0.7 \mathrm{~kg}$ of silage $\mathrm{DM} / \mathrm{kg}$ of concentrate DM) with increasing concentrate feed level (Faverdin et al., 1991; Ferris et al., 1999, 2001). However, in those studies, cows on each concentrate level were balanced for milk yield, resulting in cows with a range of yields being offered each concentrate level. In this scenario, it is likely that the lowest-yielding cows will experience the greatest levels of substitution. In contrast, within a feed-to-yield approach, only higher-yielding cows are offered higher levels of concentrates, and these cows also tend to have a greater overall DMI and, thus, the 
potential to maintain forage DMI despite increasing levels of concentrates being offered. This is in agreement with the finding of an earlier study by P. J. Purcell (Agri-Food and Biosciences Institute, Hillsborough, UK, personal communication), in which the forage DMI of cows offered concentrates on an individual cow basis decreased by $0.07 \mathrm{~kg} / \mathrm{kg}$ of concentrate DM over a range in concentrate intakes $(6.3-13.5 \mathrm{~kg}$ of $\mathrm{DM} / \mathrm{d})$. The low level of substitution in these 2 studies supports the practical assumption often used when rationing cows, namely that the basal diet is able to sustain a relatively constant level of performance for cows with a range of milk yield potentials. Nevertheless, both studies provide some evidence of decreasing forage intakes with higher-yielding cows, and it is likely that increased precision could be achieved when rationing cows by accounting for this decrease.

\section{Indicators of Digestive Function}

The effect of treatment on the silage-to-concentrate ratio of the diets consumed is evident in Figure 2, with cows on the individual cow treatment experiencing a wide range of silage-to-concentrate DM ratios, whereas for cows on the group treatment the ratio remained constant across the range of milk yields observed. Although not reflected in the treatment mean data for milk fat content, the higher concentrate proportion with the higher-yielding cows on the individual cow treatment is likely to have contributed to the greater reduction in milk fat concentration described earlier. Although part of this reduction may be due to a dilution effect associated with higher milk volumes, the high-concentrate proportions are likely to have affected rumen function, with an associated decrease in acetateto-propionate ratio (Van Soest, 1963) or other ruminal mechanisms involving CLA isomers (Bauman et al., 2008). In addition, the higher-concentrate proportion experienced by the higher-yielding cows on the individual cow treatment may have put these cows at a greater risk of low rumen pH (Agle et al., 2010) and SARA (Krause and Oetzel, 2006). Fecal consistency scoring is often proposed as a clinical indicator for rumen health assessments associated with sub-acute ruminal acidosis (Atkinson, 2013), with manure consistency a function of feed moisture content and the mean retention time of the feed in the digestive tract (Kononoff et al., 2002). In a previous study, Ireland-Perry and Stallings (1993) observed that cows offered low-forage diets had a lower fecal consistency score. Nevertheless, in the present study, concentrate allocation strategy had no effect on fecal scores.

Similarly, data describing fecal residue fractions at d 30 and 60 postcalving suggest little effect of con- centrate allocation strategy on particle size, although an increased number of longer particles were observed with the individual cow treatment at d 90 postcalving. This could be explained by a lower rumen $\mathrm{pH}$, a consequence of the higher concentrate feed levels with the higher-yielding cows (Agle et al., 2010), leading to a decrease in the number of fibrolytic rumen bacteria (Strobel and Russell, 1986; Plaizier et al., 2008) and an associated poorer breakdown of fiber particles. In addition, higher intakes with the higher-yielding cow on this treatment, and an associated increased rate of passage (Krizsan et al., 2010), might also have contributed to poorer particle breakdown in the rumen. Nevertheless, it is unclear why such an effect was only observed at d 90 postcalving.

\section{$B W, B C S$, and Energy Balance}

Whereas cows in the individual cow treatment tended to lose more $\mathrm{BW}$ to nadir than cows in the group treatment, this difference was relatively minor $(10 \mathrm{~kg})$. The absence of any large effect of concentrate allocation strategy on BW or BCS values over the study period supports the similar energy balance trends observed during the experimental period, in agreement with Purcell et al. (2016). In contrast, Rijpkema et al. (1990) found that cows on an individual cow strategy lost BW over the study period whereas cows on a flatrate strategy had a modest BW gain; Lawrence et al. (2015) observed an increased BCS loss (0.1 units) over the study period with cows on a flat-rate treatment compared with an individual cow treatment. Although the reasons for these inconsistent findings between studies are unclear, the outcomes of the current study were not unexpected, given that neither total DMI nor fat plus protein yield were affected by treatment.

Figure 1d highlights the fact cows on both treatments remained in NEB throughout most of the study period, although neither the BW nor condition score data suggest such an extensive period of NEB. For example, cows on the individual cow and group treatments reached nadir BW at 60 and 52 d postcalving, respectively. Nevertheless, it is known that BW change is not always an accurate predictor of energy balance, with Beever et al. (1998) and Cammel et al. (2000) observing that cows remained in NEB for 20 and 24 wk postcalving, respectively, despite starting to gain BW from approximately wk 6 postcalving. Similar prolonged periods of NEB have been observed in earlier studies undertaken at this institute, involving diets similar to those offered in the current study (Law et al., 2009).

The relationship between daily energy balance and milk yields (Figure 3 ) demonstrates a clear trend within 
both treatments for higher-yielding cows to experience a greater mean daily NEB than lower-yielding cows. However, the slope of the response line with the individual cow treatment $(-2.07 \mathrm{MJ} / \mathrm{kg}$ of milk) compared with the group treatment $(-3.39 \mathrm{MJ} / \mathrm{kg}$ of milk) demonstrates that as yields increased, cows on the individual cow treatment did not experience as severe a NEB as cows on the group treatment. This is not unexpected, given that the individual cow treatment was designed to meet the additional energy requirements of higheryielding cows through additional concentrate feeding. The fact that the energy balance of higher-yielding cows on this treatment was not closer to zero energy balance is perhaps surprising, given the individual cow management strategies adopted. However, this effect can be explained by differences in cow BW (with correspondingly higher maintenance energy requirements), the adoption of a common feed rate $(0.45 \mathrm{~kg} / \mathrm{kg}$ of milk), which takes no account of cows producing milk with an improved composition compared with the assumed standard milk, the imperfect assumption of a common level of performance sustained by the basal diet across a range of performance levels, and an overestimation of performance sustained by the basal diet. This demonstrates the need to develop individual cow management strategies that take account not just of individual milk yields, but of individual cow parameters such as body size, milk composition, and actual intakes.

\section{Fertility Performance}

Few studies have examined the effects of concentrate allocation strategy on fertility performance. Within the current study, concentrate allocation strategy had no effect on the time to resumption of estrus activity (as measured by onset of corpus luteal activity) or the number of cows with an estrus event by d 42, with almost all cows having had at least an estrus event by d 70 postcalving. However, conception rates to first and second service, and $100 \mathrm{~d}$ in-calf rates, were lower with the group treatment, whereas a tendency was noted for a lower number of cows to be treated with progesterone (used to treat cessation of cyclicity) in the individual cow treatment. In contrast, Taylor and Leaver (1984a,b) found calving interval to be unaffected by allocation strategy and Purcell et al. (2016) found conception rate to first service to be unaffected. Energy balance is known to be a primary driver of reproductive success (Ingvartsen, 2006; Drackley and Cardoso, 2014), in particular, the extent of NEB during the early postpartum period (Butler and Smith, 1989). For example, increased NEB is known to delay first ovulation (Butler, 2003) and to decrease oocyte quality (Jorritsma et al., 2003). Nevertheless, mean daily energy balance was unaffected by treatment in the current study. Similarly, whereas Mann et al. (2005) observed that increased milk yields were associated with an increase in cycle abnormalities (including cessation of cyclicity), in the current study we found no indication of an increased incidence of progesterone treatments with higher-yielding cows. In view of the relatively small number of cows in our study, the results of improved fertility in the individual cow treatment must be treated with caution.

\section{CONCLUSIONS}

This study demonstrated that for groups of cows with a reasonably tight calving pattern, mean cow performance (DMI, milk production, milk composition, and body tissue changes) was unaffected when a grass silage-based diet was supplemented with similar amount of concentrates, either on a group or individual cow basis for 20 wk postcalving. However, concentrate allocation strategy did have an effect on the individual performance of cows, with cows on the individual cow treatment having a greater range of concentrate intakes and milk yields than those on the group allocation strategy. The improved pregnancy rates with the individual cow allocation treatment need to be treated with caution.

\section{ACKNOWLEDGMENTS}

Thanks are due to the Dairy Unit staff at the AgriFood and Biosciences Institute Hillsborough for care of the experimental animals and for assisting with experimental measurements. This study was co-funded by the Department of Agriculture and Rural Development for Northern Ireland (DARDNI) and AgriSearch (Northern Ireland farmer levy). Mark Little acknowledges receipt of a $\mathrm{PhD}$ studentship from AgriSearch.

\section{REFERENCES}

Agle, M., A. N. Hristov, S. Zaman, C. Schneider, P. M. Ndegwa, and V. K. Vaddella. 2010. Effect of dietary concentrate on rumen fermentation, digestibility, and nitrogen losses in dairy cows. J. Dairy Sci. 93:4211-4222.

Agnew, R. E., T. Yan, J. France, E. Kebreab, and C. Thomas. 2004. Feed into Milk. A new applied feeding system for dairy cows. Nottingham University Press, Nottingham.

Atkinson, O. 2013. A cross-sectional survey to investigate prevalence of and clinical indicators for Subacute Ruminal Acidosis (SARA) in lactating cows on UK dairy farms. RCVS Diploma in Cattle Health and Production dissertation. Royal College of Veterinary Surgeons (RCVS), London, UK.

Bauman, D. E., J. W. Perfield 2nd, K. J. Harvatine, and L. H. Baumgard. 2008. Regulation of fat synthesis by conjugated linoleic acid: Lactation and the ruminant model. J. Nutr. 138:403-409.

Beever, D. E., S. B. Cammel, J. D. Sutton, N. Rowe, and G. E. Perrott. 1998. Energy metabolism in high yielding cows. Pages 13-14 
in Proc. British Society of Animal Science. Br. Soc. Anim. Sci., Penicuik, UK.

Bell, A. W. 1995. Regulation of organic nutrient metabolism during transition from late pregnancy to early lactation. J. Anim. Sci. 73:2804-2819.

Butler, W. R. 2003. Energy balance relationships with follicular development, ovulation and fertility in postpartum dairy cows. Livest. Prod. Sci. 83:211-218.

Butler, W. R., and R. D. Smith. 1989. Interrelationships between energy balance and postpartum reproductive function in dairy cattle. J. Dairy Sci. $72: 767-783$.

Cammel, S. B., D. E. Beever, J. D. Sutton, J. France, G. Alderman, and D. J. Humphries. 2000. An examination of energy utilization in lactating dairy cows receiving a total mixed ration based on maize ailage. Anim. Sci. 71:585-596.

Cushnahan, A., and F. J. Gordon. 1995. The effects of grass preservation on intake, apparent digestibility and rumen degradation characteristics. Anim. Sci. 60:429-438.

Dale, A. J., S. McGettrick, A. W. Gordon, and C. P. Ferris. 2016. The effect of two contrasting concentrate allocation strategies on the performance of grazing dairy cows. Grass Forage Sci. http:// dx.doi.org/10.1111/gfs.12185.

Drackley, J. K., and F. C. Cardoso. 2014. Prepartum and postpartum nutritional management to optimize fertility in high-yielding dairy cows in confined TMR systems. Animal 8(Suppl. 1):5-14.

Edmonson, A. J., I. J. Lean, L. D. Weaver, T. Farver, and G. Webster 1989. A body condition scoring chart for holstein dairy cows. J. Dairy Sci. 72:68-78.

Farm Animal Welfare Council. 1997. Report on the welfare of dairy cattle. Ministry of Agriculture, Fisheries and Food, Tolworth/Surbiton, Surrey, UK.

Faverdin, P., J. P. Dulphy, J. B. Coulon, R. Vérité, J. P. Garel, J. Rouel, and B. Marquis. 1991. Substitution of roughage by concentrates for dairy cows. Livest. Prod. Sci. 27:137-156.

Ferris, C. P., F. J. Gordon, D. C. Patterson, D. J. Kilpatrick, C. S. Mayne, and M. A. McCoy. 2001. The response of dairy cows of high genetic merit to increasing proportion of concentrate in the diet with a high and medium feed value silage. J. Agric. Sci. 136:319-329

Ferris, C. P., F. J. Gordon, D. C. Patterson, C. S. Mayne, and D. J. Kilpatrick. 1999. The influence of dairy cow genetic merit on the direct and residual response to level of concentrate supplementation. J. Agric. Sci. 132:467-481.

Ferris, C. P., F. J. Gordon, D. C. Patterson, C. S. Mayne, and M. A. McCoy. 2003. A short-term comparison of the performance of four grassland-based systems of milk production for autumn-calving dairy cows. Grass Forage Sci. 58:192-209.

Finneran, E., P. Crosson, P. O'Kiely, L. Shalloo, D. Forristal, and M. Wallace. 2012. Stochastic simulation of the cost of home-produced feeds for ruminant livestock systems. J. Agric. Sci. 150:123-139.

García, S. C., M. Pedernera, W. J. Fulkerson, A. Horadagoda, and K. Nandra. 2007. Feeding concentrates based on individual cow requirements improves the yield of milk solids in dairy cows grazing restricted pasture. Aust. J. Exp. Agric. 47:502-508.

Gordon, F. J. 1982. The effects of degree of chopping grass for silage and method of concentrate allocation on the performance of dairy cows. Grass Forage Sci. 37:39-46.

Grummer, R. R., D. G. Mashek, and A. Hayirli. 2004. Dry matter intake and energy balance in the transition period. Vet. Clin. North Am. Food Anim. Pract. 20:447-470.

Hills, J. L., W. J. Wales, F. R. Dunshea, S. C. Garcia, and J. R. Roche. 2015. Invited review: An evaluation of the likely effects of individualized feeding of concentrate supplements to pasture-based dairy cows. J. Dairy Sci. 98:1363-1401.

Ingvartsen, K. L. 2006. Feeding- and management-related diseases in the transition cow: Physiological adaptations around calving and strategies to reduce feeding-related diseases. Anim. Feed Sci. Technol. 126:175-213.

Ingvartsen, K. L., and K. Moyes. 2013. Nutrition, immune function and health of dairy cattle. Animal 7(Suppl. 1):112-122.
Ireland-Perry, R. L., and C. C. Stallings. 1993. Fecal consistency as related to dietary composition in lactating Holstein cows. J. Dairy Sci. 76:1074-1082.

Jorritsma, R., T. Wensing, T. A. Kruip, P. L. Vos, and J. P. Noordhuizen. 2003. Metabolic changes in early lactation and impaired reproductive performance in dairy cows. Vet. Res. 34:11-26.

Kononoff, P., J. Keinrichs, and G. Varga. 2002. Using manure evaluation to enhance dairy cattle nutrition. Penn State Extension. Accessed Mar. 3, 2016. http://extension.psu.edu/animals/dairy/ nutrition/nutrition-and-feeding/troubleshooting-guides/usingmanure-evaluation-to-enhance-dairy-cattle-nutrition.

Krause, K. M., and G. R. Oetzel. 2006. Understanding and preventing subacute ruminal acidosis in dairy herds: A review. Anim. Feed Sci. Technol. 126:215-236.

Krizsan, S. J., S. Ahvenjärvi, and P. Huhtanen. 2010. A meta-analysis of passage rate estimated by rumen evacuation with cattle and evaluation of passage rate prediction models. J. Dairy Sci 93:5890-5901.

Law, R. A., F. J. Young, D. C. Patterson, D. J. Kilpatrick, A. R. G. Wylie, and C. S. Mayne. 2009. Effect of dietary protein content on animal production and blood metabolites of dairy cows during lactation. J. Dairy Sci. 92:1001-1012.

Lawrence, D. C., M. O’Donovan, T. M. Boland, E. Lewis, and E. Kennedy. 2015. The effect of concentrate feeding amount and feeding strategy on milk production, dry matter intake, and energy partitioning of autumn-calving Holstein-Friesian cows. J. Dairy Sci $98: 388-348$.

Leaver, J. D. 1988. Level and pattern of concentrate allocation to dairy cows. Pages 315-326 in Nutrition and Lactation in the Dairy Cow. P. C. Garnsworthy, ed. Butterworth-Heinemann, Oxford, UK.

Maltz, E., L. F. Barbosa, P. Bueno, L. Scagion, K. Kaniyamattam, L. F. Greco, A. De Vries, and J. E. P. Santos. 2013. Effect of feeding according to energy balance on performance, nutrient excretion, and feeding behavior of early lactation dairy cows. J. Dairy Sci. 96:5249-5266

Maltz, E., S. Devir, O. Kroll, B. Zur, S. L. Spahr, and R. D. Shanks. 1992. Comparative responses of lactating cows to total mixed rations or computerized individual concentrates feeding. J. Dairy Sci. $75: 1588-1603$.

Mann, G. E., S. J. Mann, D. Blache, and R. Webb. 2005. Metabolic variables and plasma leptin concentrations in dairy cows exhibiting reproductive cycle abnormalities identified through milk progesterone monitoring during the postpartum period. Anim. Reprod. Sci. 88:191-202.

McCleary, B. V., V. Solah, and T. S. Gibson. 1994. Quantitative measurement of total starch in cereal flours and products. J. Cereal Sci. 20:51-58.

Moisey, F. R., and J. D. Leaver. 1985. Systems of concentrate allocation for dairy cattle 3. A comparison of two flat-rate feeding systems at two amounts of concentrates. Anim. Sci. 40:209-217.

Oltenacu, P. A., and D. M. Broom. 2010. The impact of genetic selection for increased milk yield on the welfare of dairy cows. Anim. Welf. 19:39-49.

Park, R. S., R. E. Agnew, F. J. Gordon, and R. W. J. Steen. 1998. The use of near infrared reflectance spectroscopy (NIRS) on undried samples of grass silage to predict chemical composition and digestibility parameters. Anim. Feed Sci. Technol. 72:155-167.

Plaizier, J. C., D. O. Krause, G. N. Gozho, and B. W. McBride. 2008 Subacute ruminal acidosis in dairy cows: The physiological causes, incidence and consequences. Vet. J. 176:21-31.

Porter, M. G. 1992. Comparison of sample preparation methods for the determination of the gross energy concentration of fresh silage. Anim. Feed Sci. Technol. 37:201-208.

Porter, M. G., and R. S. Murray. 2001. The volatility of components of grass silage on oven drying and the inter-relationship between drymatter content estimated by different analytical methods. Grass Forage Sci. 56:405-411.

Purcell, P. J., R. A. Law, and C. P. Ferris. 2015. Effect of concentrate allocation strategy on the performance of dairy cows in early to midlactation. Adv. Anim. Biosci. 6:192 
Purcell, P. J., R. A. Law, A. W. Gordon, S. A. McGettrick, and C. P. Ferris. 2016. Effect of concentrate feeding method on the performance of dairy cows in early-to-mid lactation. J. Dairy Sci. In press.

Rijpkema, Y. S., L. Van Reeuwijk, and P. W. Goedhart. 1990. Effects of pattern of concentrate feeding on milk production of dairy cows offered silage ad libitum. Neth. J. Agric. Sci. 38:461-474.

Roche, J. R., N. C. Friggens, J. K. Kay, M. W. Fisher, K. J. Stafford, and D. P. Berry. 2009. Invited review: Body condition score and its association with dairy cow productivity, health, and welfare. J. Dairy Sci. 92:5769-5801.

Roche, J. R., J. K. Kay, N. C. Friggens, J. J. Loor, and D. P. Berry. 2013. Assessing and managing body condition score for the prevention of metabolic disease in dairy cows. Vet. Clin. North Am. Food Anim. Pract. 29:323-336.

Sauer, M. J., J. A. Foulkes, A. Worsfold, and B. A. Morris. 1986. Use of progesterone 11-glucuronide-alkaline phosphatase conjugate in a sensitive microtitre-plate enzymeimmunoassay of progesterone in milk and its application to pregnancy testing in dairy cattle. J. Reprod. Fertil. 76:375-391.

Steen, R. W. J. 1989. A comparison of soya-bean, sunflower and fish meals as protein supplements for yearling cattle offered grass silage-based diets. Anim. Sci. 48:81-89.

Strobel, H. J., and J. B. Russell. 1986. Effect of pH and energy spilling on bacterial protein synthesis by carbohydrate-limited cultures of mixed rumen bacteria. J. Dairy Sci. 69:2941-2947.
Taylor, W., and J. D. Leaver. 1984a. Systems of concentrate allocation for dairy cattle 1 . A comparison of three patterns of allocation for autumn-calving cows and heifers offered grass silage ad libitum. Anim. Sci. 39:315-324.

Taylor, W., and J. D. Leaver. 1984b. Systems of concentrate allocation for dairy cattle 2. A comparison of two patterns of allocation for autumn-calving cows offered two qualities of grass silage ad libitum. Anim. Sci. 39:315-324.

Van Arendonk, J. A. M., G. J. Nieuwhof, H. Vos, and S. Korver. 1991. Genetic aspects of feed intake and efficiency in lactating dairy heifers. Livest. Prod. Sci. 29:263-275.

Van Soest, P. J. 1963. Ruminant fat metabolism with particular reference to factors affecting low milk fat and feed efficiency. A review. J. Dairy Sci. 46:204-216.

Veerkamp, R. F. 1998. Selection for economic efficiency of dairy cattle using information on live weight and feed intake: A review. J. Dairy Sci. 81:1109-1119.

Wilkinson, M., and J. Allen. 2015. Trends in efficiency of compound feed use by dairy cows in Great Britain. Adv. Anim. Biosci. 6:106.

Zaaijer, D., and J. P. T. M. Noordhuizen. 2003. A novel scoring system for monitoring the relationship between nutritional efficiency and fertility in dairy cows. Ir. Vet. J. 56:145-151. 